\title{
A REGIONÁLIS PÓRUSNYOMÁSVISZONYOK JELENTŐSÉGE A TERMÁLVÍZ FELTÁRÁSÁBAN ÉS A KÉSZLETEK MEGÚJULÁSÁBAN
}

\section{SIGNIFICANCE OF REGIONAL PRESSURE CONDITIONS IN THERMAL WATER EXPLORATION AND THE REJUVENATION OF GEOTHERMAL RESOURCES}

\author{
Mádlné Szőnyi Judit \\ PhD, Eötvös Loránd Tudományegyetem Általános és Alkalmazott Földtani Tanszék, Budapest \\ szjudit@ludens.elte.hu
}

ÖSSZEFOGLALÁS

Hazánkban megfigyelhető a felszín alatti fluidumokkal és hasznosításukkal foglalkozó jogszabályok összehangolatlansága. A Pannon-medencében a vízfogó és vízvezető képződmények összefüggő rendszerében a termálvíztározó a vízfogókon és szerkezeti elemeken keresztül kölcsönhatásban áll az ivóvíztermelésre használt rétegekkel és a medence szénhidrogén-rezervoárjaival is. A tanulmány rámutat arra, hogy a rezervoármérnöki megközelítés mellett szükség van a medence különböző fluidumai hidraulikai összefüggéseinek megértésére ahhoz, hogy összehangoljuk a hasznosításukat. Ebben segíthet a regionális nyomásviszonyok megértése, amelyet a tanulmány a termálvíz feltárása és a készletek megújulása szempontjából értékel.

\begin{abstract}
The legislation for underground fluids of Hungary is diverse and not harmonized. In the aquifer and aquitard systems of the Pannonian basin the thermal water reservoirs are connected through aquitards and tectonic elements to 'drinking water' and hydrocarbon reservoirs. The study reveals the necessity of understanding the hydraulic interrelationships of the basin simultaneously with the existing reservoir-engineering approach, to plan the aligned utilization of different fluids. For this purpose we propose the approach of regional pressure conditions which is discussed from perspective of thermal water exploration and rejuvenation of the fluid.
\end{abstract}

Kulcsszavak: geotermia, folyadékpotenciál, regionális nyomásviszonyok, kockázat, jogi szabályozás

Keywords: geothermics, fluid potential, regional pressure regime, risk, legislation 


\section{BEVEZETÉS, PROBLÉMAFELVETÉS}

Amikor geotermikus kutatásba kezdünk egy-egy területen, először a természetes geotermikus rendszer (Dickson-Fanelli, 2013) elemeit kell számba vennünk, ezek a hő, a megfelelő tározókőzet (rezervoár) és a fluidum jelenléte. Ezek felmérése és ezek alapján a geotermikus potenciál értékelése segít megtalálni a geotermikus energia feltárására és kiaknázására leginkább megfelelő technológiát. Mára a rendszer valamely elemének hiányában annak mesterséges pótlása is lehetséges (például Enhanced Geothermal Systems). A geotermikus potenciál értékelése során - a mai gyakorlat alapján - feltételezik, hogy megfelelő vízvezető képességü vagy permeabilitású tározókőzet (például homokkő vagy mészkö) esetén a geotermikus fluidum is rendelkezésre áll.

Gondot okozhat, ha az alkalmazott koncepcionális modellünk és a „készletek müködése" nincs összhangban (Lovekin, 1998). A geotermiában használatos, előzőekben vázolt modell a litológia alapján feltételezi elegendő pórusfluidum rendelkezésre állását, azonban nem számol azzal, hogy a vizsgált rezervoár hidrogeológiai környezete és a terület fejlődéstörténete is befolyásolhatja azt. S bár kis valószínűséggel, de előfordulhat olyan helyzet, hogy egy előzetesen minden tekintetben (a rezervoár porozitása, permeabilitása és a várható hőmérséklet, magas geotermikus gradiens szempontjából) kiváló potenciálú helyen sem lesz sikeres a termálvízfeltárás. Maga a fogalom, a „termálvíztározó” kifejezés is megtévesztő abban az értelemben, hogy belőle a víz lokalizált (elkülönült) víztározóban való jelenlétére asszociálhatunk.

Feltehetjük a kérdést, hogy a jelenleg használt modellünk valóban leképezi-e a „készletek múködését”? Több évtizede tudjuk, hogy üledékes medencékben, így a Pannon-medencében is, hidraulikailag összefüggő víztartó és vízfogó képződmények rendszerével számolhatunk. Ezekben a termálvíztározó nem kezelhető elkülönült egységként, ugyanis az a vízfogókon és szerkezeti elemeken keresztül kölcsönhatásban áll az ivóvíztermelésre használt rezervoárokkal és a medence szénhidrogénrendszereivel is.

A föntiekből adódó problémák igen sokrétủek, amelyek az érvényben lévő törvényi szabályozásban is tükröződnek, a végrehajtásában pedig gondot okoznak. Az 1993. évi XLVIII. törvény a bányászatról mesterséges, $2500 \mathrm{~m}$-es mélységhatárral választja el az alatta elhelyezkedő zárt geotermikus rendszereket és a fölötte lévő nyitott tározókat. A zárt rendszerben, kizárólag energetikai célra használt termálvíz visszasajtolása a törvény szerint kötelező, de ez csak a zárt tározókra vonatkozik. Megfigyelhető a felszín alatti vizekkel foglalkozó jogszabályok, valamint a geotermikus és szénhidrogén-koncesszióra vonatkozó törvények összehangolatlansága is, amire számos példát lehetne felsorolni. Megállapíthatjuk, hogy a Pannon-medencére vonatkozóan a csapadékból pótló- 
dó ${ }^{1}$ (nyitott) és nem pótlódó ${ }^{2}$ (zárt) készletek tudományos értelmủ elkülönítése medenceszinten és hidraulikai értelemben még nem történt meg.

\section{MEGKÖZELITTÉS, CÉLOK}

Következésképpen a lokális, ún. rezervoármérnöki közelítés mellett - amely a tározó termelése szempontjából nélkülözhetetlen - szükség van a felszín alatti régió fluidumai (felszín alatti víz - ivóvíz vagy termálvíz -, olaj, gáz) hidraulikai összefüggéseinek megértésére is ahhoz, hogy azok hasznosítását összehangoljuk. Ez pedig a lokális megközelítéstől fogalmi használatában és értelmezésében is elkülönülő, medenceléptékü közelítést igényel. Ebben kíván elmozdulást elérni az a Horizon 2020 projekt (ENeRAG, Excellency Network Building for Comprehensive Research and Assessment of Geofluids), mely 2018-ban indult az Eötvös Loránd Tudományegyetem konzorciumvezetésével a Milánói Egyetem és a Finn Földtani Intézet közremüködésével, és amely a témában együttmüködést kezdeményez a Magyar Bányászati és Földtani Szolgálat, az Országos Vízügyi Felügyelet, a Budapest Gyógyfürdői és Hévizei Zrt., valamint geotermikus cégek bevonásával.

A medenceléptékủ megközelítés igényli a „természetes geotermikus rendszer" előzőekben vázolt elemeinek medenceméretekben való megértését, kiegészítve azt a hidraulikai, azaz a víztartó és a vízfogó rétegek között fennálló összefüggések megismerésével. Jelen tanulmányban ezek közül csak a fluidumpotenciál-tér ${ }^{3}$, ezen belül is a regionális pórusnyomásviszonyok jelentöségével és értelmezésével foglalkozom. Tanulmányomban ennek értékelési módszereit mutatom be. Az elvek alkalmazásának lehetséges gyakorlatát is tárgyalom egy értékelési séma formájában, mely a geotermikus készletek megújulásával és az injektálás hidraulikai lehetőségeivel foglalkozik. Az elveket a Budai-termálkarszt és a Gödöllői-dombság tágabb környezete példáján szemléltetem.

\footnotetext{
${ }^{1}$ Csapadék beszivárgása útján a készletek pótlódása lehetséges.

${ }^{2}$ E készletek a kőzetváz és a fluidum rugalmas tulajdonságai révén termelhetők ki. Pótlódásuk a csapadékból nem lehetséges.

3 A folyadékpotenciál a felszín alatti fluidum egységnyi tömegre eső összes mechanikai energiáját fejezi ki. Jelentősége, hogy eloszlása meghatározza a felszín alatti fluidumokra ható hajtóerőteret. A fluidumok a nagyobb potenciálú felől a kisebb potenciálú medencerészek felé áramlanak.
} 


\section{NYOMÁSREZSIMEK ÉS A FLUIDUMPOTENCIÁL-TÉR MEDENCELÉPTÉKŰ HIDRAULIKAI ÉRTÉKELÉSE}

A medenceléptékü hidraulikai megközelítés módszertanát Tóth József (2009) könyve részletesen tárgyalja. Az elemzés alapját a kutak létesítéskori dokumentációi adják (kútadatok, kútkönyvek, víz- és hévízföldtani naplók: Egységes Országos Vetület (EOV) koordináták, a hidraulikai/nyomásmérési hely tengerszint feletti magassága, a hidraulikus emelkedési magasság, pórusnyomás, a kútban megnyitott szakasz teteje és alja, valamint ezek tengerszint feletti magassága). A medenceléptékü hidraulikai elemzés során a hidraulikus folytonosság elvét használjuk, amely a teljes vizsgált területet - a felszíntől a medence aljáig, beleértve a víztartókat és vízfogókat - egységesen kezeli és értékeli (Tóth, 1995; Tóth, 2009). A kutakban mért hidraulikus emelkedési magasság és pórusnyomás adatai alapján a folyadékpotenciál-teret vizsgáljuk.

Az alkalmazott módszerek közül ebben a tanulmányban csak a vertikális nyomásprofilt és a potenciáltérképet említem. A nyomás-eleváció/tengerszint feletti magasság, azaz a $p(z)$ profilokat néhány $10 \mathrm{~km}^{2}$-en belül található, különböző szintre szürőzött kutak pórusnyomására (vagy nyugalmi vízszintböl ${ }^{4}$ számolt pórusnyomására) vonatkozó adatokból szerkesztjük (1. ábra). Ezekből a fluidumáramlás vertikális komponensének nagyságára, irányára, valamint az adott szintben várható hidrosztatikus nyomástól való eltérés mértékére következtethetünk. Hidrosztatikus nyomásviszonyok fennállása esetén a függőlegesen lefelé irányuló nyomásnövekedés mértékét kifejező vertikális nyomásgradiens, $\gamma=9,81 \mathrm{kPa} / \mathrm{m}$. A vertikális nyomásgradiens a pórusfolyadék sürüsége függvényében eltérő lehet, ezért a medenceléptékü értékeléshez egy viszonyító gradienst alkalmazunk. Jelen esetben a viszonyító gradiens: az édesvíz fajsúlya alapján $\left(\gamma_{\mathrm{st}}\right)$. Ekkor nincs vertikális folyadékáramlás, ugyanis az elemi folyadékrészecskére ható gravitációs erő és a hajtóerő vertikális komponense kiegyenlítik egymást. Hidrodinamikai állapotban a hajtóerő a rendszert kimozdítja egyensúlyi állapotából, ennek következtében vertikális irányú áramlási komponens is generálódik, így a vertikális gradiens dinamikussá válik $\left(\gamma_{\text {dyn }}\right)$. Utánpótlódási területeken $\gamma_{\text {dyn }}<\gamma_{\text {st }}$, azaz a nyomásgradiens szubhidrosztatikus, ami lefelé történő vertikális áramlást jelez. Kiáramlási területeken $\gamma_{\text {dyn }}>\gamma_{\text {st }}$, ami feláramlásra utal, ez esetben a $\gamma_{\text {dyn }}$ szuperhidrosztatikus. A középvonal- (átáramlási) területeken a vertikális nyomásgradiens hidrosztatikus, $\gamma_{\text {dyn }}=\gamma_{\mathrm{st}}$, azaz, bár a folyadékáramlásnak nincs vertikális komponense, laterális folyadékáramlás lehetséges. A szaturált pórusfolyadék-sürüségtől eltekintve a mért adatokból levezetett gradiensvonal lefutása és értéke a környező kőzetváztól is függ. Az adatok értékeléséből levezetett nyomásgradi-

4 A kutakban mérhető $h$ nyugalmi vízszint azért nagy jelentőségü, mert azt a nehézségi gyorsulással megszorozva megkapjuk a folyadékpotenciál értékét, azaz a nyugalmi vízszintet a folyadékpotenciál fokmérőjeként értékelhetjük a felszín alatti térrészben. 
ensben látható éles változások rendszerint a kőzetek hidraulikus vezetőképességének megváltozását is tükrözik (Czauner-Mádl-Szőnyi, 2013).

A kutakban mért hidraulikus emelkedési magasság és nyomásértékek alapján nemcsak a nyomásgradiens határozható meg, de a felszín alatti nyomásrezsim is, amely lehet túlnyomásos (szuperhidrosztatikus), hidrosztatikus vagy alulnyomásos (szubhidrosztatikus). A hidrodinamikai analízis során az alulnyomás $(-\Delta p)$ és a túlnyomás $(+\Delta p)$ mértéke a dinamikus nyomáseltéréssel fejezhető ki, ami az adott eleváción várható nominális vagy statikus nyomás $\left(p_{\text {nom }}\right)$ és a dinamikus vagy valós nyomás ( $\left.p_{\text {real }}\right)$ különbsége (Tóth, 2009). A folyadékpotenciál-tér anomáliái rendszerint földtani folyamatokra vezethetők vissza.

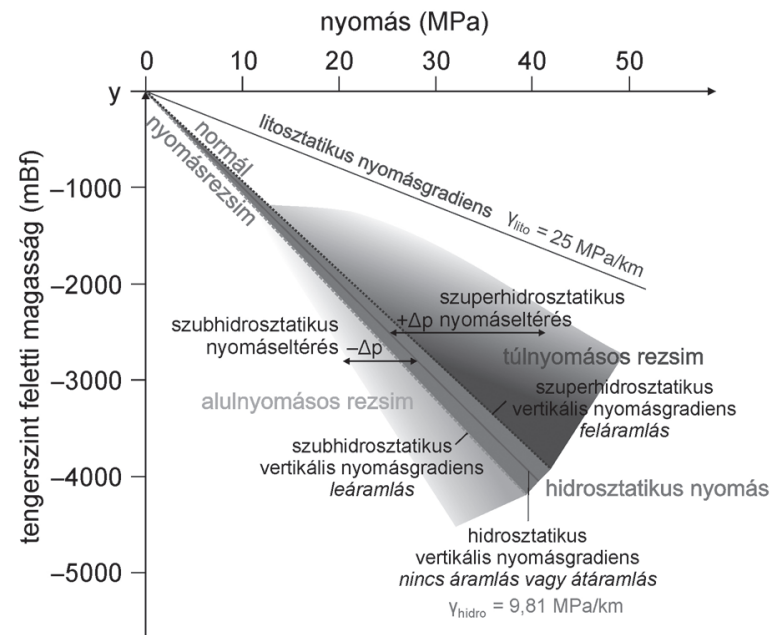

1. ábra. A nyomás-tengerszint feletti magasság profil $p(z)$ kiegészítve a hidrosztatikus $\left(1000 \mathrm{~kg} / \mathrm{m}^{3}\right.$ sủrüségű vízre vonatkoztatott) és a litosztatikus nyomást reprezentáló vonalakkal.

A hidrosztatikus vertikális nyomásgradiens vízszintes áramlásra utal vertikális komponens nélkül; a szuperhidrosztatikus vertikális nyomásgradiens vertikális feláramlást, míg a szubhidrosztatikus vertikális nyomásgradiens vertikális leáramlást jelez.

A szuper- $(+\Delta p)$ és a szubhidrosztatikus $(-\Delta p)$ nyomáseltérés a folyadékpotenciál anomáliáit jelzi (mBf: a Balti-tenger szintjétől mért magasság)

(Az ábrák a szerző szerkesztései)

A folyadékpotenciál-térkép (potenciáltérkép) a hidraulikus emelkedési magasság egy adott elevációtartományba eső értékeinek (vízszintes, X-Y síkban történő) kontúrozásával állítható elő. E térképeket a tengerszint feletti magasság egymásra következő intervallumaira szerkesztjük (a kutak szürőközépértékei mint a mérési pontok eleváció szerinti eloszlása alapján). Az ekvipotenciálok mentén a folyadékpotenciál (hidraulikus emelkedési magasság) értéke állandó. A vízszintes hajtóerő első közelítésben (homogén, izotrop közeg esetében) merőleges az 
ekvipotenciálokra. A földtani heterogenitások - mint már utaltam rá - anomáliát okoznak a folyadékpotenciál-térben, így hidraulikai hatásuk az okozott anomália alapján értékelhető. Az egymás után következő térképek összehasonlításával a vertikális áramlási komponensekre is következtethetünk.

\section{FÖLDTANI KÖRNYEZET ÉS NYOMÁSREZSIMEK}

A nyomásrezsim nem egy pontban mért nyomást jelent, hanem egy nagyobb medencerészre jellemző karakterisztikus nyomást. A különböző nyomásrezsimek szisztematikus eloszlást mutatnak az üledékes medencékben ${ }^{5}$ (Deming, 2002). Normál vagy hidrosztatikus nyomásrezsim a kontinenseken található üledékes medencékben fordul elő, amelyek kőzetvázát a csapadékból származó vizek részben (felszínközelben) vagy egészben már átjárták. Földtani és hidrogeológiai értelemben az ilyen területek vízáramlási rendszereiről feltételezhetjük, hogy időbeli változásuk medenceléptékben nem számottevő, emiatt ezeket kvázi stacionárius nyomásállapotok és vízáramlási viszonyok jellemzik.

Ezekben a medencékben hidraulikai kapcsolat áll fenn a vízfogók és a rezervoárok között. Erre utal, hogy a nyomásértékek a hidrosztatikus nyomás közelében vannak, és csak minimális nyomáseltérések figyelhetők meg a hidrosztatikus nyomáshoz viszonyítva. Amennyiben a nyomásgradiens szubhidrosztatikus, vertikális, azaz lefelé irányuló áramlást, míg a szuperhidrosztatikus vertikális nyomásgradiens felfelé irányuló áramlást jelez.

A túlnyomásos nyomásrezsim süllyedő medencékben fordul elő, elsődlegesen az üledékképződéssel járó kompakció hatására. Földtani értelemben a folyamatos üledékképződés tranziens viszonyokat idéz elő. Ugyanakkor egyéb folyamatok, például tektonikai kompresszió (a litoszféra és a benne található pórusfluidum tektonikai hatásra történő összenyomódása), akvatermális hatás (a pórusnyomás növekedése a hő hatására kitáguló pórusfolyadék miatt), konvekció (a folyadék hömérséklet- vagy sürüségkülönbsége miatt indukált áramlása következtében kialakuló túlnyomás vagy alulnyomás) is szerepet játszhatnak kialakulásában. A kontinenseken belül található medencék esetében, ha süllyedésük jelenleg is zajlik, akkor a medencék hidrosztatikus nyomással jellemezhető területei alatt is előfordul. Ez a helyzet a Pannon-medencében is.

Ezeket a medencéket fölülről, a normál nyomásrezsim felöl „zárt” hidraulikai helyzet és szuperhidrosztatikus $(+\Delta p)$ nyomáseltérés jellemzi. A kapcsolat a felső hidrosztatikus és az alsó túlnyomásos rezsim között egyirányú, azaz a túlnyomás disszipációja révén felszabaduló folyadék bekerülhet a normál nyomásrezsimü régióba. Fordítva ugyanakkor ez nem lehetséges.

${ }^{5}$ Itt csak a földtani fejlődésük során mára szárazra került medencékkel foglalkozunk. 
Emelkedő területeken az erózió csökkenti a porózus közegre nehezedő tömeget, így alulnyomásos rezsim alakulhat ki (Ingebritsen et al., 2006). Ez olyan földtani helyzetben következhet be leginkább, ahol a víztartót vastag, kis permeabilitású fedö borítja. A kis permeabilitású fedő részleges lepusztulásának hatására a víztartó kőzetvázának relaxációja következik be, viszont az alacsony permeabilitás miatt a fedőrétegen át történő utánpótlódás mértéke földtani időskálán nem tart lépést a víztartó fluidum befogadóképességének növekedésével. A hőkonvekció is okozhat alulnyomást. Ezek mindegyike geológiai értelemben tranziens folyamat.

Alulnyomásos esetben a nyomásértékek számottevően alacsonyabbak a hidrosztatikus nyomás alapján várható értékeknél. Az alulnyomás mértékét a szubhidrosztatikus nyomáseltéréssel $(-\Delta p)$ jellemezhetjük. Ebben a helyzetben a fedett víztartó nyelőként funkcionál, vizet fogad be környezetéből.

\section{A REGIONÁLIS NYOMÁSREZSIMEK ÉRTELMEZÉSE A GEOTERMIKUS KÉSZLETEK MEGÚJULÁSA ÉS A VISSZASAJTOLÁS SZEMPONTJÁBÓL}

A normál vagy hidrosztatikus nyomásrezsim azt fejezi ki, hogy a kőzetvázban (a vízvezetőkön és vízfogókon keresztül) lehetséges a fluidum mozgása, ennek megfelelően a nyomás ki tud egyenlítődni. Ebből arra is következtethetünk, hogy a kőzetváz direkt kapcsolatban van a vízkörforgalommal, azaz első közelítésben megújuló készleteket tartalmaz. (A vízrészecskék tényleges kicserélődésének és az utánpótlódás módjának, mennyiségének meghatározásához azonban további módszerek, hidrológiai vizsgálatok, numerikus szimuláció, stabil és radioaktív izotópok alkalmazása szükséges.) Amennyiben a termelés az utánpótlódás mértékét nem haladja meg, a felszín alatti vízkészletek megújulása lehetséges. Ugyanakkor az utánpótlódásnál intenzívebb termelés már visszasajtolást igényel. A visszasajtolási nyomás mértéke a vertikális nyomásgradiensek ismeretében előzetesen tervezhető. Ha feláramlás vagy horizontális irányú áramlás zajlik, akkor kis nyomású besajtolás szükséges. Ezzel szemben lefelé történő vízáramlás esetén a víz energiabefektetés nélkül elnyelethető a kútban (2. ábra).

Abnormálisan magas pórusnyomás esetén a hidrosztatikus nyomáshoz képest számottevően nagyobb nyomás miatt a régió vízbefogadásra nem képes, ugyanakkor a túlnyomás lecsengése révén fluidumot adhat le kisebb nyomású környezete felé, azaz a fölötte található közel hidrosztatikus nyomású régióba. Ezekbe a túlnyomásos rendszerekbe tehát csapadékbeszivárgás nem lehetséges, így vízkészletük nem megújuló. Belőlük a pórusfluidum a rétegek rugalmas összenyomódása és a víz kitágulása révén szabadítható fel. A rugalmas tulajdonságok folyamatos kimerülése időben csökkenő térfogatú vízmennyiség kitermelését teszi lehetővé, ezért a termelés itt csak visszasajtolással lehetséges. 
Az alulnyomásos rezsim a környezetéből fluidumbefogadásra képes, azaz injektálásra alkalmas, a folyadék elnyeletése hidraulikai értelemben ezekbe a rétegekbe energiabefektetés nélkül lehetséges. Ugyanakkor, mivel ezeknél az utánpótlódás geológiai időskálán korlátozott, ezért vízkészletük nem megújuló, mi több, ebből adódóan nem is termelhető.

Természetesen mind az injektálás, mind a termelés csak megfelelö permeabilitású vízvezető képződményekbe vagy rezervoárokba lehetséges, ezzel azonban itt nem foglalkozom bővebben.

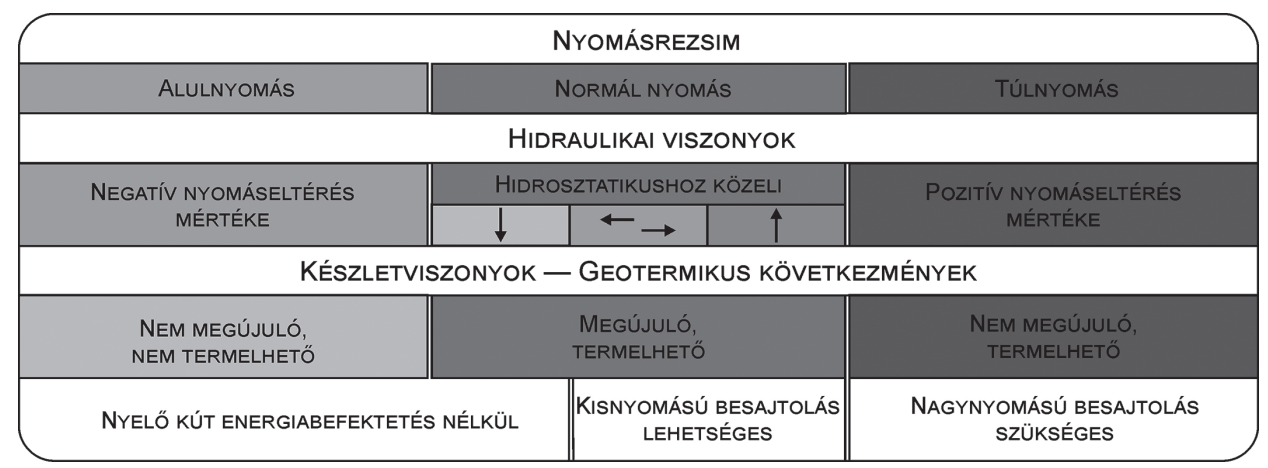

2. ábra. Értékelési séma a regionális nyomásviszonyok és a hidraulikai helyzet figyelembevételére a geotermikus készletek megújulása és a visszasajtolási lehetőségek szempontjából

\section{A NYOMÁSREZSIMEK ÉRTÉKELÉSE A BUDAI-TERMÁLKARSZT ÉS GÖDÖLLŐI-DOMBSÁG TÁGABB KÖRNYEZETÉBEN}

A Budai-termálkarszt és a Gödöllői-dombság a Pannon-medence geotermikus szempontból kulcsfontosságú területe. Itt találhatók a budapesti meleg és langyos vizü források, amelyek a felszín alatti vízáramlások kiáramlási területei. E területen karbonátos (mészkő és dolomit) triász (HSG1 VV) és eocén víztartók (HSG2 VV-[VF]) jellemzőek, amelyek közepes/jó/kiváló vízvezető képességgel jellemezhetők $\left(K=10^{-6}-10^{-3} \mathrm{~m} / \mathrm{s}\right)(3$. ábra).

Ezek a víztartók a Dunától Ny-ra a felszínen, DK felé egyre mélyebb helyzetben, dominánsan sziliciklasztos (agyagmárga, agyag, homok) képződmények alatt fedett állapotban találhatók (-2000 mBf-től egészen -3500 mBf-ig). A víztartók ÉNy-DK-i irányú szerkezeti elemekkel tagoltak, a területen belül kulcsfontosságú oldaleltolódási zóna a Balaton-Tóalmás-vonal. A víztartóban a hőmérsékleti viszonyok is többnyire kedvezőek, $-1000 \mathrm{mBf}$ alatt $30-130{ }^{\circ} \mathrm{C}$ közötti hőmérsékletértékekkel. A terület karbonátos víztartói tehát alkalmasak a 
hévízfeltárásra. Hagyományos megközelítéssel a vízadók hidraulikus vízvezető képessége és a hőmérsékletviszonyok alapján értékelhető a geotermikus feltárás lehetősége.

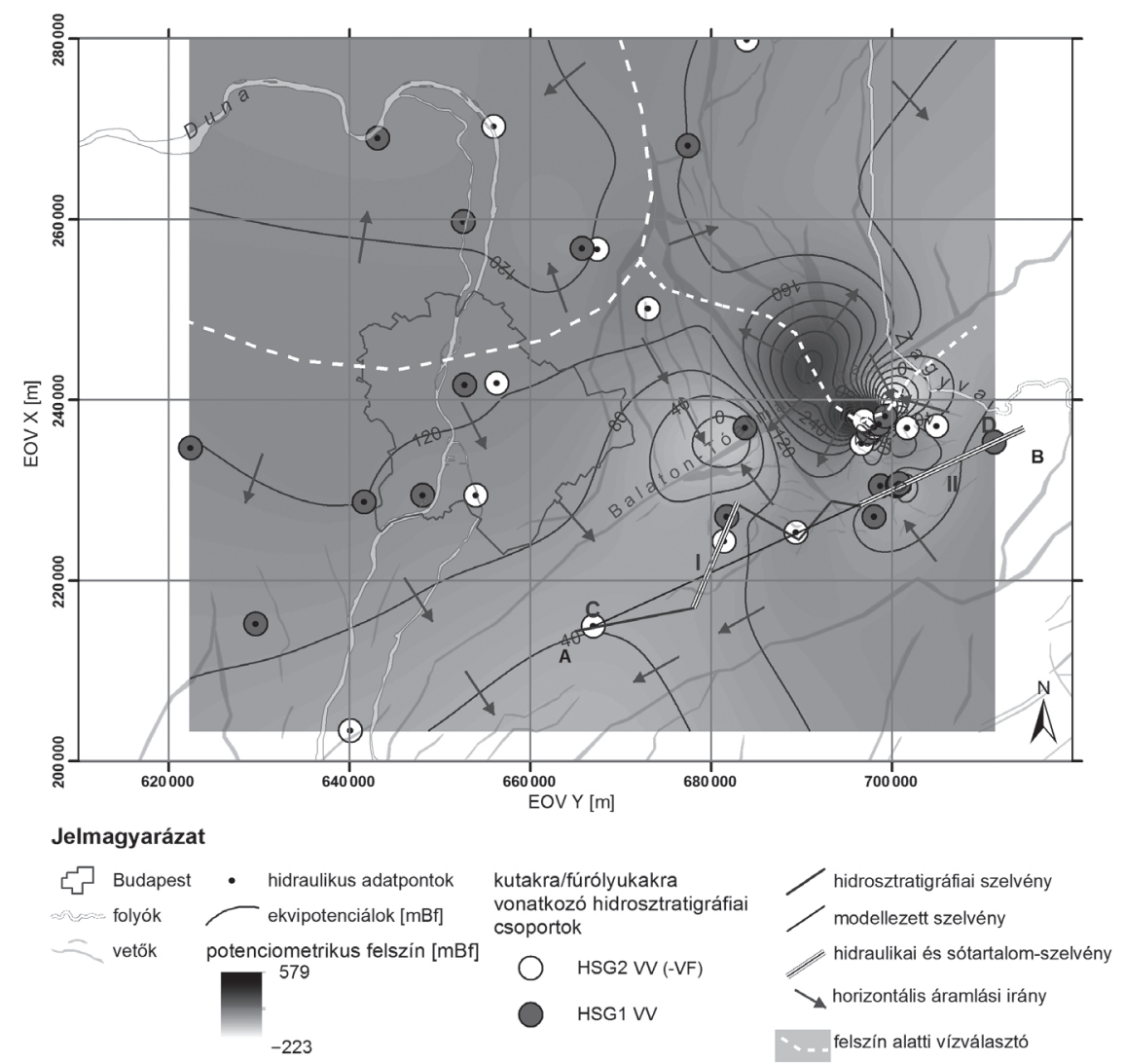

3. ábra. Potenciometrikus térkép a (-1000 mBf alatti szürőzésü) karbonátos víztartóba mélyült kutak $h$ adataiból szerkesztve, a horizontális áramlási irány és a felszín alatti vízválasztók feltüntetésével

A terület regionális hidraulikai feldolgozási eredményei Mádl-Szőnyi Judit és szerzőtársai (2019) tanulmányában olvashatók. A karbonátos víztartókra szerkesztett (-1000 mBf alatti szürőzésü) kutak hidraulikus emelkedési magasság $(h)$ adataiból szerkesztett potenciometrikus térképen a kutak által megnyitott víztartót is megjelenítettük (HSG1 vagy HSG2). A $h$ értékek alapján kvázi normál potenciáleloszlású területeket ( $\sim 120 \mathrm{~m})$ és karakterisztikus anomáliákat (pozitív, $h>160 \mathrm{~m}$ és negatív, $h<80 \mathrm{~m}$ ) is el tudtunk különíteni a potenciáltérben a Balaton-Tóalmás-vonal környezetében (3. ábra). 
A $p(z)$ profilok alapján Diósd (1) környezete normál hidrosztatikus nyomásrezsimmel és leáramlással, a Margit-sziget (2) környezete szintén hidrosztatikushoz közeli nyomásrezsimmel és feláramlással jellemezhető (4. ábra). Isaszegnél (3) a normál, leáramlással jellemezhető nyomásrezsim mellett már megjelenik a tényleges alulnyomás. A Balaton-Tóalmás-vonaltól D-re található Gomba (4) terület karbonátjai alulnyomással jellemezhetők. Ugyanakkor a turai (5) blokk túlnyomásos, míg Tóalmásnál (6) a túlnyomás és alulnyomás együttes jelenlétével számolhatunk, Nagykátán (7) normál-alulnyomásos a rezervoár. Mindezek, mint korábban bemutattuk, a hőmérséklet és a rezervoár paraméterei mellett szintén befolyásolják a geotermikus lehetőségeket a készletek termelhetősége (azaz utánpótlódása) és az injektálás szempontjából.

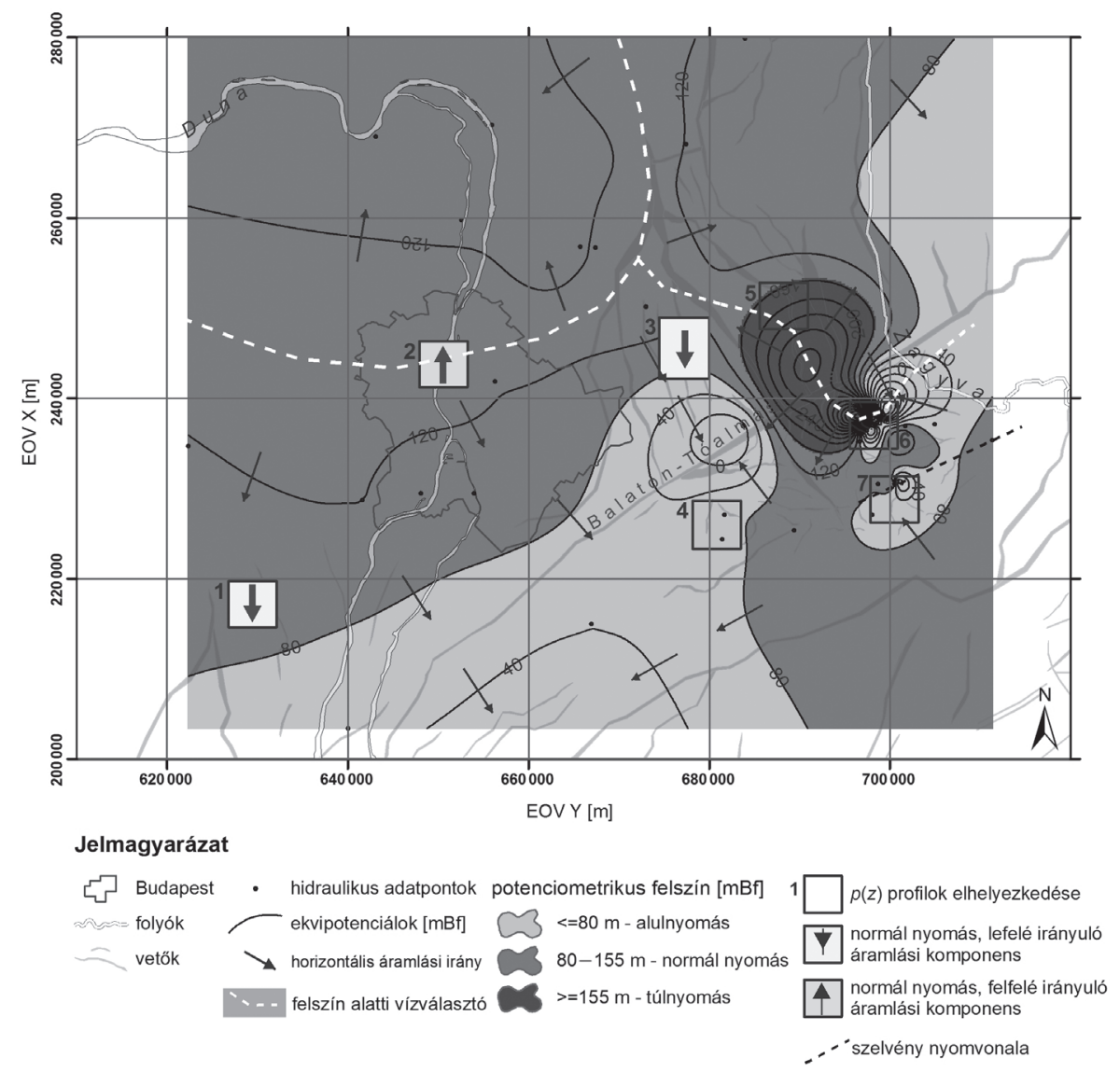

4. ábra. A potenciáltérképből levezetett nyomásrezsimtérkép, amely a normál, hidrosztatikus, valamint a túlnyomásos és alulnyomásos medencerészeket jelzi, kiegészítve a $p(z)$ profilok helyével és értelmezett nyomásrezsimével 
A regionális nyomásrezsim mint figyelembe nem vett kockázati tényező lehetséges jelentőségét egy, a területen felhagyott fúrásos geotermikus feltárás is megerősíti. Bár a kutatás felhagyásának valós oka pontosan nem ismert, a feltárás a minden szempontból perspektivikus gödöllői területen nem vezetett eredményre. Ugyanakkor a turai első geotermikus kiserőmủ a nyomásrezsimek szempontjából is kedvező régióban létesült.

\section{ÖSSZEFOGLALÁS, KÖVETKEZTETÉSEK}

A geotermikus készletek hagyományos értékelése során a természetes geotermikus rendszer elemeit veszik számba, ugyanakkor nem számolnak azzal, hogy a fluidumok rendelkezésre állása még kiváló vízvezető képességü kőzet esetén sem garantált. E kockázati tényező kiküszöbölésére szolgál a regionális nyomásrezsimek értékelése, ami medencehidraulikai módszerekkel (potenciometrikus térképek és vertikális nyomásprofilok) történhet. A nyomásrezsimek lehatárolása révén információ nyerhető a normál, valamint a túlnyomásos, alulnyomásos régiók medencén belüli helyzetéböl. Mi több, ez alapot ad egy előzetes értékelési séma kialakítására a geotermikus készletek megújulására és az injektálásra vonatkozóan. A bemutatott esettanulmány a nyomásrendszerek értékelését, geotermikus célú értelmezését és gyakorlati hasznosíthatóságát szemlélteti. A bemutatott medencehidraulikai megközelítés a jogi-szabályozási kérdések megvitatásához és hatékonyabb kezeléséhez is hozzájárulhat.

\section{KÖSZÖNETNYILVÁNÍTÁS}

A szerző köszönetét fejezi ki a MOL NyRt. (UX2315.39.78/95), NKFI/OTKA (101356) és az ENeRAG (810980) projektek támogatásáért, valamint a kutatásban közremüködő kollégáknak: Szkolnikovics-Simon Szilvia, Zentainé Czauner Brigitta, Iván Veronika, Tóth Ádám, Erőss Anita, Pulay Eszter, Kovácsné Bodor Petra, Sőreg Viktor, Boncz László, Havril Tímea és Szijártó Márk. Az utóbbi két kollégának köszönöm a kézirat alapos átolvasását.

\section{IRODALOM}

Czauner B. - Mádl-Szőnyi J. (2013): Regional Hydraulic Behavior of Structural Zones and Sedimentological Heterogeneities in an Overpressured Sedimentary Basin. Marine and Petroleum Geology, 48, 260-274. DOI: 10.1016/j.marpetgeo.2013.08.016

Deming, D. (2002): Introduction to Hydrogeology. New York: McGraw-Hill 
Dickson, M. H. - Fanelli, M. (2013): Geothermal Energy: Utilization and Technology. Routledge Ingebritsen, S. E. - Sanford, W. E. - Neuzil, C. E. (2006): Groundwater in Geologic Processes. Cambridge University Press

Lovekin, J. W. (1998): Sustainable Geothermal Power: The Life-cycle of a Geothermal Field. GRC Transactions, 22, 515-519. https://catalog.data.gov/dataset/sustainable-geothermal-power-the-life-cycle-of-a-geothermal-field

Mádl-Szőnyi J. - Czauner B. - Iván V. et al. (2019): Confined Carbonates - Regional Scale Hydraulic Interaction or Isolation? Marine and Petroleum Geology, 107, 591-612. DOI: 10.1016/j.marpetgeo.2017.06.006, http://real.mtak.hu/80484/1/Madl_Szonyi_et_al_2017_confined_carbonates_u.pdf

Tóth J. (1995): Hydraulic Continuity in Large Sedimentary Basins. Hydrogeology Journal, 3, 4, 4-16. DOI: $10.1007 / \mathrm{s} 100400050250$

Tóth J. (2009): Gravitational Systems of Groundwater Flow: Theory, Evaluation, Utilization. Cambridge University Press 